\title{
HIGH-LEVEL RADIOACTIVE SOLID WASTE FORM EVALUATION: MODEL FOR PREDICTING LEACHING BEHAVIOR
}

\author{
Ahmad Gabr Solomah and Lloyd R. Zumwalt \\ North Carolina State University, P.O. Box 5995, Raleigh, North Carolina 27650, USA
}

\begin{abstract}
Chemical stability, in particular the leaching resistance of sintered modified SYNROC-B ceramic waste form, has been studied at leaching temperatures of 25,75 , and $150^{\circ} \mathrm{C}$ in deionized $\mathrm{H}_{2} \mathrm{O}$. The leach rate data of the tests are reported and compared with the leach rate data of borosilicate glass (PNL 72-68) at $75^{\circ} \mathrm{C}$ under similar conditions. New leaching quantities, incremental erosion rate $\left[E_{r}(T)\right]$ and accumulated eroded layer $[\epsilon(T)]$ have been introduced in this study to represent the leaching behavior of the proposed solid waste forms. The accumulated eroded layer has been expressed by a linear combination of two possible release mechanisms: [1] a transient first-order dissolution reaction and [2] a mass diffusion of the radioactive ions from the interior of the solid to the surface. Experimental data from current leaching tests for modified SYNROC-B at 25 and $150^{\circ} \mathrm{C}$ were found to fit the proposed model very well, but with different dissolution reaction rate constants, which indicate the effect of temperature on such a release mechanism. The applicability of the model and its accuracy are discussed.
\end{abstract}

\section{INTRODUCTION}

High-level radioactive waste (HLW) generated from light water reactor (LWR) spent fuel reprocessing (commercial waste) or from weapons technology (government waste) may require solidification and incorporation into an inert and durable host matrix suitable for deep geologic disposal. The proposed or selected host matrix must have high chemical stability, radiation resistance, and thermomechanical integrity during long-term $\left(10^{5}-10^{6}\right.$ years) disposal. Glass and its derivatives have long been considered as host matrices for HLW because of their adequate durability. This, coupled with economical considerations and opportunities to make use of well known glass technology, mean that full-scale production might be achieved in a short period of time (1). However, zinc borosilicate glass was not entirely stable under very high temperature leach conditions $\left(700^{\circ} \mathrm{C}\right.$ for one week) where it devitrified, exposing more surface to attack by the leachant $\left(\mathrm{H}_{2} \mathrm{O}\right)$, subsequently releasing more HLW ions to the surrounding media (2).

Several crystalline waste forms have been considered as alternative HLW host matrices. One of the

\footnotetext{
RECEIVED 3/6/82; ACCEPTED 3/15/82.

Acknowledgment-This work was funded in part by the Department of Energy (DOE) through Savannah River Operations Office under the Contracts DE-AC09-80ET41902 and DE-AC09$81 \mathrm{SR} 10957$.
}

proposed crystalline waste forms is SYNROC-B (3), a synthetic mineral assemblage consisting of three phases: Ba-Hollandite $\left(\mathrm{BaAl}_{2} \mathrm{Ti}_{6} \mathrm{O}_{16}\right)$, Perovskite $\left(\mathrm{CaTiO}_{3}\right)$, and Zirconolite $\left(\mathrm{CaZrTi}_{2} \mathrm{O}_{7}\right)$. These three phases have mineral analogs found in crustal rocks, which have contained naturally occurring uranium, thorium, and their decay products for millions of years without significant release of radioactivity to the biosphere (4).

Processing of SYNROC-B ceramics by use of a subsolidus sintering technique has been described (5). This technique includes dry powder processing [dry ball milling of the matrix components $\left(\mathrm{Al}_{2} \mathrm{O}_{3}\right)$, $\mathrm{BaCO}_{3}, \mathrm{CaCO}_{3}, \mathrm{TiO}_{2}$, and $\mathrm{ZrO}_{2}$ ) and simulated waste (PW-4b or PW-4b-7) followed by binder/lubricant addition], and both precalcining $\left[\sim 770^{\circ} \mathrm{C}\right]$ and solid state sintering $\left[-1260{ }^{\circ} \mathrm{C}\right]$ in a reducing atmosphere $\left[A R-4 \% \quad H_{2}\right]$ to achieve the appropriate valence states of simulated HLW ions to permit their incorporation with SYNROC-B constituents, ending up with the desired crystalline host phases.

The chemical stability of the sintered modified SYNROC-B ceramic waste form has been investigated $(6,7,8)$ in different leaching media (deionized $\mathrm{H}_{2} \mathrm{O}$ and various simulated brines) under conditions simulating those expected within deep geologic disposal sites (boiling at atmospheric pressure and at $\sim 270^{\circ} \mathrm{C}$ at a pressure of $-50 \mathrm{~atm}$ ).

Although one must be concerned with the very 
long-term disposal period (approaching $10^{5}-10^{6}$ years) of any proposed HLW solid waste form, actual leaching experiments have been conducted over comparatively short times (days and months) only. Prediction of the chemical stability of any proposed solid waste form over the very long-term disposal period is uncertain. To assist in reducing that predictive uncertainty the data obtained from leachability studies have been utilized in modeling possible HLW release mechanisms involving a linear combination of [1] a first-order dissolution reaction and [2] a mass diffusion process involving transport of HLW ions from the interior of the solid waste form to its surface (8).

\section{EXPERIMENTAL PROCEDURE}

Recent leaching studies of sintered modified SYNROC-B waste form containing $10 \mathrm{wt} . \%$ simulated HLW (PW-4b) have been carried out under different leaching conditions. Samples of rectangular geometry of $\sim 1-\mathrm{cm}^{2}$ surface area were diamond cut (200 grit) and prepared and tested according to the requirements and procedures recommended by the Materials Characterization Center (MCC-1 and MCC-2 Leach Tests) (9). The composition of the specimens, after sintering, has been determined by Electron Microprobe Analysis.* The density of the material was $4.1 \mathrm{~g} \mathrm{~cm}^{-3}$ ( $\sim 95 \%$ of theoretical densi-

*Electron Microprobe Analyzer, Philips Model MAR/3, operating voltage $20 \mathrm{kV}$ at $60 \sim 80 \mu \mathrm{A}, 15.5^{\circ}$ take-off angle with a beam spot of $\sim 7 \mu \mathrm{m}$ (larger than the grain size) and IBM system 370 Model 165 computer for data analysis. ty). Table 1 shows the results obtained by the microprobe, on a fractured surface, in comparison with the nominal (green) composition prior to sintering. The leaching medium was distilled $\mathrm{H}_{2} \mathrm{O}$ and the leaching temperatures were 25 and $150^{\circ} \mathrm{C}$. The elemental concentrations of the simulated HLW ions which were released to the leachant during the leaching experiments were determined by neutron activation analysis (NAA) $(10,11)$. Samples of the pure leachant (distilled $\mathrm{H}_{2} \mathrm{O}$ ) in the absence of sample material also were analyzed to determine the background concentration. Leaching data obtained elsewhere for sintered modified SYNROC-B and PNL 72-68 glass both at $75^{\circ} \mathrm{C}$ in distilled $\mathrm{H}_{2} \mathrm{O}$ (12) are presented in this paper for comparison.

The incremental leach rate, $L_{i}(T)$, of a specific ion, $i$, either from the matrix components or from the simulated radioactive waste addition, after leaching period, $t$, ending at cumulative time $T$, can be calculated according to the following equation:

$$
L_{i}(T)=\left[\frac{a_{i}(t)}{A_{i}^{0}(T)}\right]\left[\frac{W_{0}}{S t}\right] \quad \mathrm{g} \mathrm{cm}^{-2} \mathrm{~d}^{-1},
$$

where $a_{i}(t)=$ the activity of ion, $i$, found in the leachant after leaching time, $t$, days;

$A_{i}^{0}(T)=$ the original total activity of ion, $i$, found in the solid sample after a decay time of $T$ days;

$W_{0}=$ the weight of the solid sample, $\mathrm{g}$;

$S=$ the actual or geometric surface area of the exposed solid, $\mathrm{cm}^{2}$;

$t=$ the leaching interval, days;

$T=$ cumulative time from initiation of

TABLE 1

Electron Microprobe Analysis ${ }^{2}$ for Modified SYNROC-B + 10 wt.\% Simulated High-Level Waste (PW-4b)

\begin{tabular}{|c|c|c|c|c|c|c|}
\hline \multirow[b]{2}{*}{ Element } & \multirow[b]{2}{*}{ Oxide } & \multirow{2}{*}{$\begin{array}{l}\text { Composition }{ }^{b} \\
\text { Oxide wt. } \%\end{array}$} & \multicolumn{3}{|c|}{$\begin{array}{c}\text { Electron Microprobe } \\
\text { Analysis on } \\
\text { Fracture Surface }\end{array}$} & \multirow{2}{*}{$\begin{array}{c}\text { Difference } \\
\text { Oxide wt. } \%\end{array}$} \\
\hline & & & at $\%$ & wt. $\%$ & Oxide wt. $\%$ & \\
\hline Al & $\mathrm{Al}_{2} \mathrm{O}_{3}$ & 8.18 & 5.07 & 5.19 & 9.82 & +1.64 \\
\hline $\mathrm{Ba}$ & $\mathrm{BaO}$ & 10.31 & 1.72 & 9.21 & 10.28 & -0.03 \\
\hline $\mathrm{Ca}$ & $\mathrm{CaO}$ & 8.25 & 3.86 & 5.23 & 7.32 & -0.93 \\
\hline $\mathrm{Ce}$ & $\mathrm{CeO}_{2}$ & 1.48 & 0.17 & 0.90 & 1.11 & -0.07 \\
\hline $\mathrm{Cs}$ & $\mathrm{Cs}_{2} \mathrm{O}$ & 0.75 & 0.09 & 0.43 & 0.46 & -0.11 \\
\hline $\mathrm{Fe}$ & $\mathrm{Fe}_{2} \mathrm{O}_{3}$ & 0.99 & 0.22 & 0.47 & 0.67 & -0.32 \\
\hline Mo & $\mathrm{MoO}_{3}$ & 1.69 & 0.25 & 0.92 & 1.38 & -0.31 \\
\hline Nd & $\mathrm{Nd}_{2} \mathrm{O}_{3}$ & 2.26 & 0.35 & 1.75 & 2.04 & -0.22 \\
\hline $\mathrm{Ni}$ & $\mathrm{NiO}$ & 0.29 & 0.13 & 0.28 & 0.36 & +0.07 \\
\hline $\mathrm{Sr}$ & $\mathrm{SrO}$ & 0.57 & 0.11 & 0.38 & 0.45 & -0.12 \\
\hline $\mathrm{Ti}$ & $\mathrm{TiO}_{2}$ & 57.16 & 19.68 & 36.66 & 61.15 & +3.99 \\
\hline $\mathbf{U}$ & $\mathrm{UO}_{2}$ & 0.63 & 0.05 & 0.46 & 0.52 & -0.11 \\
\hline \multirow[t]{2}{*}{$\mathrm{Zr}$} & $\mathrm{ZrO}_{2}$ & 7.44 & 1.57 & 4.97 & 6.47 & -0.93 \\
\hline & & 100.00 & & & 102.03 & +2.03 \\
\hline
\end{tabular}

${ }^{a}$ The at $\%$ and wt. $\%$ are averaged over four different measurements and the attenuation (absorption) of the matrix is neglected. The standards were the oxides of the elements.

${ }^{b}$ Calculated nominal composition. 
leaching to the end of current period, day.

The leaching intervals were carried out in sequential periods (e.g., 3, 4, 7, 14, 28, and 36 days) with a cumulative leaching time of 92 days. Figure 1 shows the leach rate of Cs for sintered modified SYNROC-B containing $10 \mathrm{wt} . \%$ simulated HLW (PW-4b) at 25 , 75 , and $150^{\circ} \mathrm{C}$ and for PNL 72-68 waste glass at $75{ }^{\circ} \mathrm{C}$.

New leaching quantities have been introduced in this study to explain the behavior of the proposed solid waste form under leaching conditions incremental erosion rate, $E_{r}(T)$, and the accumulated eroded layer, $\epsilon(T)$. The incremental erosion rate is defined as

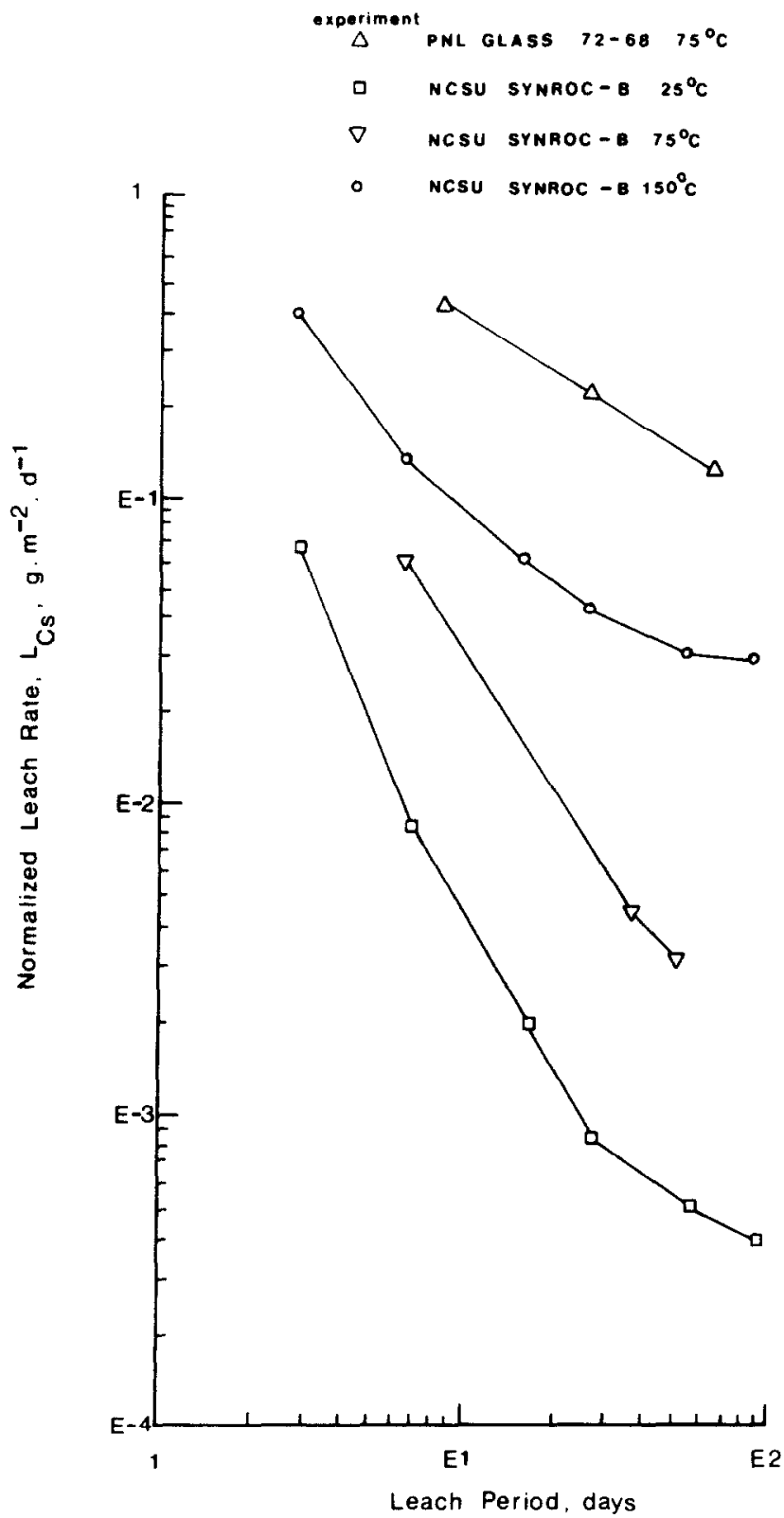

FIGURE 1. Incremental leach rate of $\mathrm{Cs}, L_{\mathrm{CS}}$, for sintered modified SYNROC-B containing $10 \mathrm{wt} . \%$ simulated HLW (PW-4b) and PNL 72-68 waste glass in deionized $\mathrm{H}_{2}$ at different leach temperatures.

$$
E_{r}(T)=\frac{L_{i}(T)}{\rho} \mathrm{cm} \mathrm{d}^{-1},
$$

where $L_{i}(T)$ is the incremental leach rate of HLW ion, $i,\left(\mathrm{~g} \mathrm{~cm}^{-2} \mathrm{~d}^{-1}\right)$ and $\rho$ is the density of solid waste form $\left(\mathrm{g} \mathrm{cm}^{-3}\right)$.

The accumulated eroded layer, $\epsilon(T)$, is simply the integral (or the sum) of $E_{r}(T)$ over the entire cumulative leaching period, $T$, which is directly proportional to the fractional release of radioactivity. With the assumption that the entire solid matrix will erode (or disappear) by the same rate of the most leachable species of HLW (i.e., Cs). Figure 2 shows the accumulated eroded layer (from experimental data) of sintered modified SYNROC-B and PNL 72-68 waste glass over the cumulative leaching periods based on the leach rate for Cs (see Fig. 1).

The use of these new leaching quantities, $E_{r}(T)$ and $\epsilon(T)$, is to help provide the answer to the most important questions in this type of study: What will be the life span of the proposed solid waste form? What is the predictive behavior of the selected waste form beyond the leaching test period which is very

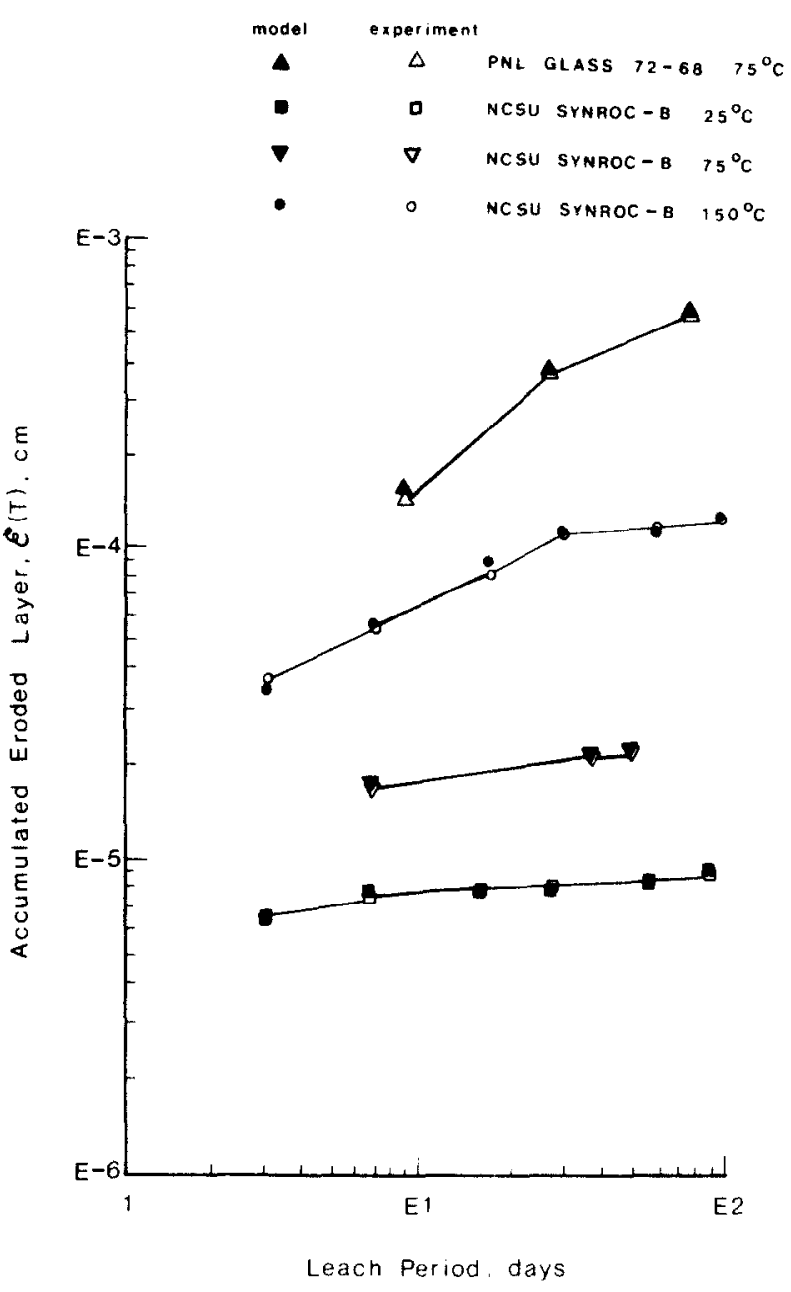

FIGURE 2. Accumulated eroded layer, $\epsilon(T)$, for sintered modified SYNROC-B containing $10 \mathrm{wt} . \%$ simulated HLW (PW-4b) and PNL 72-68 waste glass based on leach rate data of $\mathrm{Cs}$ in deionized $\mathrm{H}_{2} \mathrm{O}$ at different leach temperatures. 
short, almost negligible, in time with respect to the very long-term disposal time? An accurate prediction is highly desirable but at this point of time can only be tentative.

\section{MODEL FORMULATION AND DATA ANALYSIS}

Different model components of mass (radioactivity) transport have been deduced for considering the interaction of the radioactive solid waste form with the aqueous solution (deionized water or brine). Some of those models lead to either illogical or unrealistic predictions when published data are extrapolated to long times (13). The mechanism of release of radioactivity to the surrounding solution can be considered as being rate dependent upon a dissolution controlled process, or a mass diffusion controlled mechanism, or surface sorption, or chemical precipitation, or some combination between two or more of these processes. A model for the release of HLW ions, or the accumulated eroded layer, $\epsilon(T)$, in the case of a waste material subject to corrosion due to chemical or other instability, might in the simplest case be subject to initial diffusion control followed by linear corrosion. SYNROC-B waste material is an assemblage of three phases whose natrual analogs, containing $\mathrm{U}$, Th, and their decay products, have retained these atoms for millions of years without significant release (4). Accordingly, any release that occurs from a synthetic minearl assemblage of Ba-Hollandite, Perovskite, and Zirconolite phases is postulated to be solid state diffusion controlled with some dissolution occurring initially which tends to be terminated by a protective $\mathrm{TiO}_{2}$ layer which forms on the surface. Consistent with this, the following model expresses the accumulated eroded layer, $\epsilon(T)$, which is proportional to the fractional release, in a realistic but very simple form as a linear combination of a first-order dissolution process and a mass diffusion mechanism:

$$
\epsilon(T)=A[1-\exp (-B T)]+C(T)^{1 / 2} \mathrm{~cm} .
$$

The first term represents the release of radioactivity which is controlled by first-order dissolution reaction of species on or near the surface of the solid waste form, while the second term represents the release of radioactivity controlled by mass diffusion from the interior of the matrix of the waste form to the surface of a semi-infinite medium (8). The fraction of species near the surface is proportional to $A$, the first-order rate constant is given by $B$ (time ${ }^{-1}$ ), and $C$ is proportional to the square root of the effective diffusion coefficient $\left(\mathrm{cm} \mathrm{time} \mathrm{e}^{-1 / 2}\right.$ ) for the active species in the matrix and it in turn depends on the matrix geometry. It is to be noted that Eq. 3 is subjected to the following initial condition:

$$
\epsilon(T)=0 \text { at } T=0 .
$$

Also, if $T \ll 1 / B$,

$$
\epsilon(T)=(A B) T+C(T)^{1 / 2} \mathrm{~cm},
$$

while if $T \gg 1 / B$,

$$
\epsilon(T)=A+C(T)^{1 / 2} \mathrm{~cm},
$$

Equation 4 can show the corrosion with a linear mass transfer reaction rate, $A B$, combined with the mass diffusion process and this can be valid when $T B$ $\ll 1$, that is, either for initial (very short leaching periods) or where the rate constant, $B$, is very small (i.e., where the dissolution reaction is very rapid). Equation 5 describes the leaching behavior when the dissolution reaches a constant value or the maximum and its contribution to the release of radioactivity, at that time, is negligible. Note that Eq. 5 is not applicable for short-term behavior because it does not satisfy Eq. 3a.

The experimental data of the accumulated eroded layer, $\epsilon(T)$, for sintered modified SYNROC-B at 25 , 75 , and $150^{\circ} \mathrm{C}$ and for PNL 72-68 waste glass at $75^{\circ} \mathrm{C}$ (summarized in Fig. 2) were utilized to determine the numerical values of the constants $A, B$, and $C$ for each set of data obtained from the previously described leach tests.

A nonlinear regression procedure was performed to produce least-squares or weighted least-squares estimates of the parameters (constants) $A, B$, and $C$ of the nonlinear model presented in this work describing the accumulated eroded layer which is given by Eq. 3. A modified Gauss-Newton iterative method was employed in this type of calculations (14, $15,16)$. The nonlinear regression scheme regresses the residual on the partial derivatives of the model with respect to the parameters until the iterations converge with a convergence criterion which was designated to be $10^{-8}$.

The experimental data obtained from the leaching tests for sintered modified SYNROC-B in deionized water at 25,75 , and $150^{\circ} \mathrm{C}$ were found to fit Eq. 3 very well with different values of $A, B$, and $C$ for each test temperature. The accumulated eroded layer for each data set can be modeled in the following three equations:

For $25^{\circ} \mathrm{C}$ leach test,

$$
\begin{aligned}
\epsilon(T)=6.98 \mathrm{E}-6[1-\operatorname{cxp}( & -242.02 T)] \\
& +4.42 \mathrm{E}-6(T)^{1 / 2} \mathrm{~cm} ;
\end{aligned}
$$

For $75^{\circ} \mathrm{C}$ leach test,

$$
\begin{aligned}
& \epsilon(T)=1.2 \mathrm{E}-5[1-\exp (-158.8 T)] \\
&+ 1.37 \mathrm{E}-5(T)^{1 / 2} \mathrm{~cm} ;
\end{aligned}
$$

For $150^{\circ} \mathrm{C}$ leach test,

$$
\begin{aligned}
\epsilon(T)=4.33 \mathrm{E}-5[1-\exp (-72.53 T)] \\
+1.6 \mathrm{E}-4(T)^{1 / 2} \mathrm{~cm} .
\end{aligned}
$$


TABLE 2

Comparison Between the Model, Eqs. 6 and 8, and the Experimental Values of the Accumulated Eroded Layer, $\epsilon(T)$

\begin{tabular}{cccccccc}
\hline & \multicolumn{3}{c}{$\begin{array}{c}25{ }^{\circ} \mathrm{C} \text { Leach Test Data } \\
\epsilon(T) \times 10^{-6} \mathrm{~cm}\end{array}$} & & \multicolumn{3}{c}{$\begin{array}{c}150^{\circ} \mathrm{C} \text { Leach Test Data } \\
\epsilon(T) \times 10^{5} \mathrm{~cm}\end{array}$} \\
\cline { 2 - 4 } \cline { 7 - 8 } $\begin{array}{c}\text { Leach Period, } T \\
\text { Days (Year) }\end{array}$ & Model & Experiment & Accuracy $\%$ & & Model & Experiment & Accuracy \% \\
\hline $3(0.0082)$ & 6.42 & 6.44 & -0.28 & & 3.39 & 3.66 & -7.8 \\
$7(0.0192)$ & 7.52 & 7.42 & +1.42 & & 5.47 & 5.31 & +2.9 \\
$14(0.0384)$ & 7.85 & 7.9 & -0.68 & & 7.2 & 7.02 & +2.5 \\
$28(0.0768)$ & 8.2 & 8.24 & -0.43 & & 8.75 & 8.73 & +0.25 \\
$56(0.1536)$ & 8.71 & 8.78 & -0.79 & & 10.61 & 1.12 & -4.8 \\
$92(0.2521)$ & 9.1 & 9.13 & +0.75 & & 12.37 & 12.05 & +2.6 \\
\hline
\end{tabular}

While for PNL 72-68 waste glass, the experimental data of the accumulated eroded layer obtained from $75{ }^{\circ} \mathrm{C}$ leach test in deionized $\mathrm{H}_{2} \mathrm{O}$, were found to fit the following equation very well:

$$
\begin{aligned}
\epsilon(T)=3.83 \mathrm{E}-4[1-\exp (-9.74 T)] \\
+3.91 \mathrm{E}-4(T)^{1 / 2} \mathrm{~cm},
\end{aligned}
$$

where the time, $T$, is in units of years in all equations.

To illustrate the accuracy of the model described and utilized in this work, Table 2 shows the two sets of data of sintered modified SYNROC-B waste form obtained from 25 and $150^{\circ} \mathrm{C}$ leach tests.

\section{DISCUSSION AND CONCLUSION}

The mathematical model formulated and described in this work, in which the accumulated eroded layer from the proposed solid waste forms has been expressed by a linear combination of two important release mechanisms: [1] a transient first-order dissolution reaction and [2] a solid-state mass diffusion process, offers a good representation of the leaching behavior and release of radioactivity from the proposed waste form to aqueous media (leachants). It is to be noted that both the term $A$, the dissolution limit, and the term $C$ (which is directly related to the square-root of the effective diffusion coefficient of cesium in SYNROC-B samples) increase with temperature. Also, by comparison, the dissolution reaction rate constant, $B$, shows an increase with temperature. The reciprocal of this constant gives a measure of the time at which corrosion of SYNROC-B samples becomes insignificant (i.e., $T \gg 1 / B$ ) as predicted by the model. In the case of the glass waste form, the dissolution mechanism is substantial and enhancing the release of radioactivity to the leachant.

The fractional release or the accumulated eroded layer data for cesium from sintered modified SYNROC-B and PNL 72-68 waste glass forms, appears to be well represented by the model described in this study (Eq. 3), however, the caveat "be wary of ex- trapolation," is to be noted, thus longer leaching periods and more study are recommended.

\section{REFERENCES}

1. McElroy, J. L. Quarterly progress report research and development waste fixation program. PNL-2265, Battelle Pacific Northwest Laboratories (1977).

2. Mendel, J. E., Ross, W. A., Roberts, F. P., Turcotte, R. P., Katayama, Y. B., and Westsik, J. H., Jr. Thermal and radiation effects on borosilicate glass. IAEA-SM-207/100, International Atomic Energy Agency, Vienna (1976).

3. Ringwood, A. E. Safe Disposal of High Level Nuclear Reactor Wastes: A New Strategy. Australian National University Press, Canberra (1978).

4. Ringwood, A. E., Kessen, S. E., Wane, N. C., Hibberson, W., and Major, A. Immobilization of high level nuclear reactor wastes in SYNROC. Nature 278: 219-223 (1979).

5. Solomah, A. G., Hare, T. M., and Palmour, H. III. Demonstration of the feasibility of subsolidus sintering of radwaste-containing SYNROC-B composition. Nucl. Technol. 49: 183-185 (1980).

6. Solomah, A. G., Boss, C. B., Rossington, D. R., and Palmour, H., IIl. Chemical stability of sintered modified SYNROC-B ceramics containing simulated high level radioactive wastes, Presented at the 1st Annual Meeting of Canadian Nuclear Society in Montreal, Canada (June 18, 1980) and to be published in the Proceedings of the Conference.

7. Solomah, A. G. and Boss, C. B. Leachability studies for modified SYNROC-B ceramics as host matrix for simulated high level radwaste, Presented at the 82nd Annual Meeting of American Ceramics Society in Chicago, Illinois (April, 1980).

8. Solomah, A. G. and Zumwalt, L. R. HLW fixation in sintered modified SYNROC-B ceramics: Chemical stability evaluation. Trans. Am. Nucl. Soc. 35: 191 (1980).

9. Turcotte, R. P., Strachan, D. N., Mendel, J. E., Barnes, B. O., and Ross, W. A. The materials characterization center standard tests I: Proposed waste form leach tests, Abstracts of ORNL Conference on the Leachability of Radioactive Solids, Gatlinburg, TN (1980).

10. Flynn, K. F., Barletta, R. E., Jardine, L. J., and Steindler, M. J. Leach rate characterization of solid radioactive waste forms, in Scientific Basis for Nuclear Waste Management, vol. 1, edited by Gregory J. McCarthy. Plenum, New York (1979).

11. Flynn, K. F., Jardine, L. J., and Steindler, M. J. Method for determining leach rates of simulated radioactive waste forms, American Chemical Society Symposium on Radioactive Waste in Geologic Storage, ACS Symposium Series, Vol. 100, ACS National Meeting in Miami, Florida (1978). 
12. Flynn, K. F. Argonne National Laboratory, private communication (1980).

13. Claassen, H. C. Conceptual models governing leaching behavior and their long-term prediction capability, Abstracts of ORNL Conference on the Leachability of Radioactive Solids, Gatlinburg, TN (1980).
14. Hornbeck, R. W. Numerical Methods. Quantum Publishers, New York (1975).

15. SAS User's Guide, Statistical Analysis System. SAS Institute Inc., Cary, North Carolina (1979).

16. Bevington, P. R. Data Reduction and Error Analysis for the Physical Sciences. McGraw-Hill, New York (1969). 